This item was submitted to Loughborough's Research Repository by the author.

Items in Figshare are protected by copyright, with all rights reserved, unless otherwise indicated.

\title{
The interaction between design and occupier behaviour in the safety of new
} homes

PLEASE CITE THE PUBLISHED VERSION

http://dx.doi.org/10.1016/j.aap.2006.07.011

PUBLISHER

(C) Elsevier

VERSION

AM (Accepted Manuscript)

LICENCE

CC BY-NC-ND 4.0

REPOSITORY RECORD

McDermott, Hilary, Roger Haslam, and Alistair G.F. Gibb. 2019. "The Interaction Between Design and Occupier Behaviour in the Safety of New Homes”. figshare. https://hdl.handle.net/2134/8368. 
This item was submitted to Loughborough's Institutional Repository (https://dspace.lboro.ac.uk/) by the author and is made available under the following Creative Commons Licence conditions.

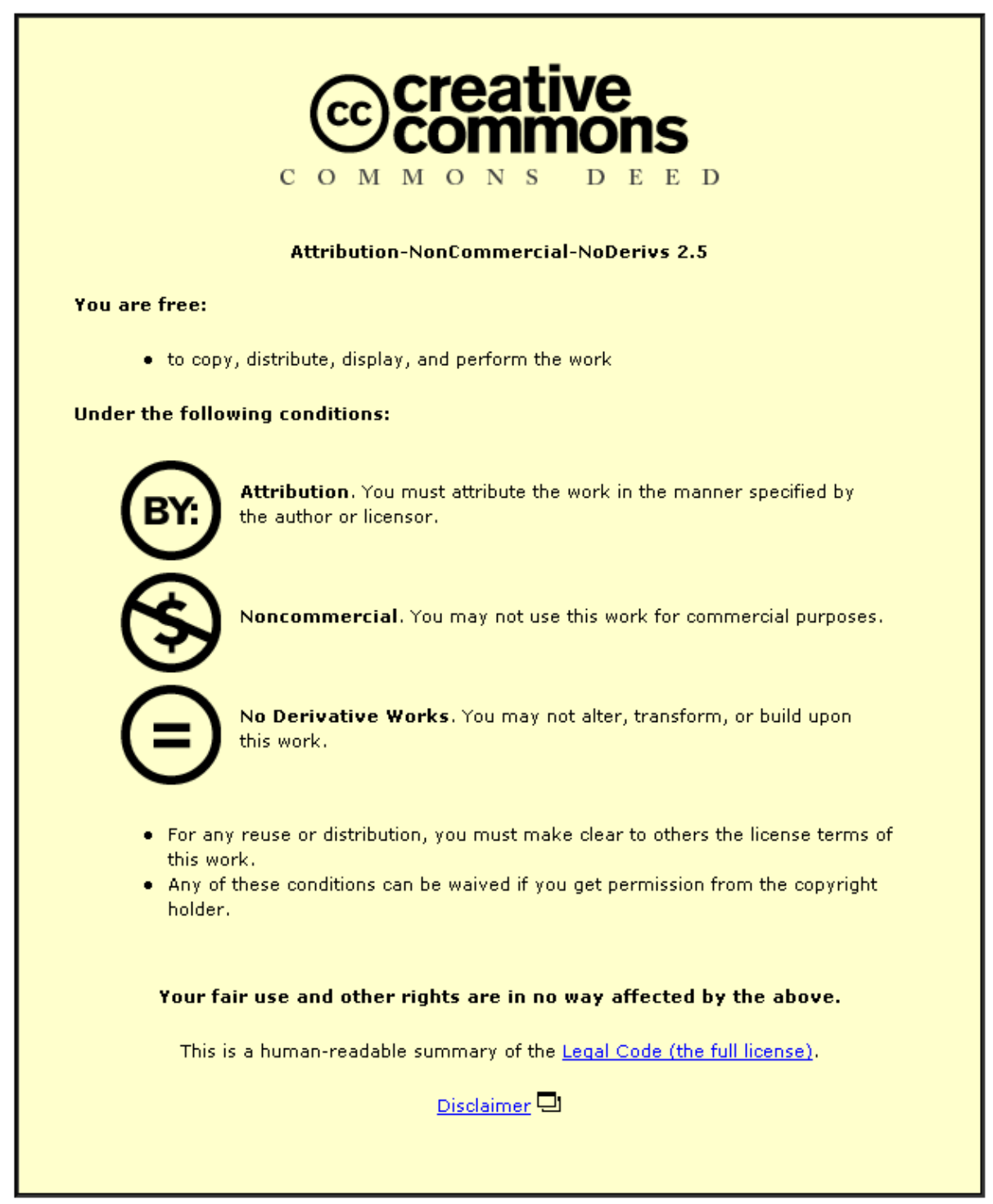

For the full text of this licence, please go to: http://creativecommons.org/licenses/by-nc-nd/2.5/ 
The interaction between design and occupier behaviour in the safety of new homes

Hilary McDermott ${ }^{1 *}$

Roger Haslam ${ }^{1}$

Alistair Gibb ${ }^{2}$

${ }^{1}$ Health and Safety Ergonomics Unit, Department of Human Sciences, Loughborough University, Loughborough, Leicestershire, LE11 3TU. England

H.J.McDermott@lboro.ac.uk

R.A.Haslam@lboro.ac.uk

${ }^{2}$ Department of Civil and Building Engineering, Loughborough University, Loughborough, Leicestershire, LE11 3TU. England

A.G.Gibb@lboro.ac.uk

* Corresponding author. Tel +44 (0)1509 228485; Fax +44 (0)1509 223940.

E-mail address: $\underline{\text { H.J.McDermott@lboro.ac.uk }}$ 


\begin{abstract}
The design of new homes includes many safety features intended to protect occupiers from injury or ill health within the home, however the effectiveness of these primary intervention measures is likely to be affected by user behaviour. This study examined the interaction between user activity and dwelling design and how this might affect health and safety. It aimed to identify how people use features within new homes and how this may limit the protection afforded by building design, codes and Regulations. Forty, home-based, semi-structured, in-depth interviews and home inspections were conducted with individuals recently inhabiting a new home. A range of behaviours were reported in relation to building features including fire doors, pipes and cables, and loft access, which may lead to increased risk of injury or ill-health. For example, occupiers described interfering with the self-closing mechanisms on fire doors and drilling into walls without considering the location of services. They also reported knowingly engaging in unsafe behaviour when accessing the loft, increasing their risk of falls. The accounts suggest that designers and builders need to give greater consideration to how occupier behaviour interacts with building features so that improvements in both design and occupier education can lead to improved health and safety.
\end{abstract}

Keywords: Design, Home Safety, Behaviour, Building Regulations. 


\subsection{Introduction}

Unintentional home injuries present a serious public health and safety problem worldwide. Within the United Kingdom, almost 4000 deaths occur annually as the result of a home accident (DTI, 1999) and almost 3 million domestic accidents arise which necessitate the casualty attending a hospital accident and emergency department (DTI, 2003). In the UK, there are more injuries and deaths as a result of an accident within the home than arise from road accidents or accidents within the working environment (Ormandy, In Press). The incidence of non-fatal home accidents within the United Kingdom is on the rise, with suggestions that this could increase by as much as 20 per cent by the year 2010 (DTI, 1999). The associated economic cost of these unintentional home injuries is estimated at $£ 25$ billion annually (RoSPA, 2005).

Reducing the incidence and severity of unintentional injuries in the UK is a public health priority (Secretary of State for Health, 1999), and various preventative measures targeting unintentional injuries have been introduced. These may be divided into three main categories; changing attitudes, changing behaviour and environmental modification. Each of these strategies has been implemented previously in the prevention of unintentional injuries within the home. 'Primary' interventions rely on a structural or environmental modification, such as improved stair design to prevent serious stair injuries, whereas 'secondary' prevention strategies require a change in attitudes or conduct of the individual, and as such, focus on the beliefs and behaviours of the occupants. Elsewhere, terms such as 'active' and 'passive' have been used as another way of categorising approaches which rely on behaviour change or modification of the environment, respectively. 
Evaluation studies have shown that primary protection through modification of design is an effective method of reducing accident incidence (Rennie \& Ford 1995). However, alongside safety improvements arising from design measures, a behavioural adaptation is often also required (Carlson Gielen \& Sleet, 2003). For example, the installation of smoke alarms in properties requires the occupants to check and maintain these safety devices in order for them to be an effective protection measure. Shults et al (1998) also highlighted the importance of this behavioural component in an evaluation of three smoke detector promotion programs. They found that in $26 \%$ of households with nonworking detectors, residents reported that they had forgotten to replace the battery.

A further limitation with environmental modification is illustrated by Heimplaetzer \& Goossens (1991,) who argued that many such primary solutions aimed at avoiding domestic accidents have been chosen on the basis of partial or incomplete modelling of these solutions. For example, in preventing children from falling down stairs a closure may be fitted at the top of a flight of stairs, but the consequences of this modification for adult occupants is overlooked. In this manner, safety measures introduced to protect occupiers from one element of danger can introduce additional hazards within the home. Pickett (2003) also highlighted this in a report on finger-trapping injury risks created by fire doors installed within domestic dwellings. In addition, Meacham (1999) argues that fire safety engineers need to recognise human behaviour and responses in their designs; the safety protection afforded by fire doors, for example, is negligible if they are wedged open or otherwise unable to close.

Human behaviour can affect the environment in two ways, either through different types of use or by changing the environment itself. This has been highlighted by Haslam et al 
(2006), for example, who identified a number of unsafe behaviours in relation to stair use amongst older people, including hurrying and the carrying of bulky or heavy items. They also identified patterns of behaviour that changed the nature of the environment, such as the leaving of obstacles on stairs. This interaction between occupier behaviour and design of the home has also been illustrated by Roys (2001) again in connection with stairs. Roys identified at least three major reasons for stair falls, these being user behaviour, maintenance and design. He argues for preventative efforts through a combination of improved stair design and user education.

Further evidence of the need to consider both behaviour and design together is offered by Ormandy (In Press). In his review of the causes of home accidents, he concludes that home safety awareness campaigns need to be complemented with housing action. In other words, interventions need to be directed at both human factors which contribute to home accidents and also dwelling factors which promote unsafe behaviour. This and the previous examples given offer strong support for a combined approach to accident prevention within the home, whereby both primary and secondary strategies are applied in combination.

With regard to behaviour change, a variety of models have been developed within the behavioural sciences which aim to predict health behaviours and these have been implemented in many areas of health promotion (Dejoy, 1996). More recently, there has been support for the implementation of these models within injury prevention (Carlson Gielen \& Sleet, 2003). Behaviour-change models have been successfully applied in other areas of injury prevention, for example, in the reduction of sports injuries (Eime et al, 2004) and reducing occupational injuries (Whysall et al, 2005). 
McLeroy et al (1988) proposed an ecological model of heath behaviour that identified a number of levels of influence on health. Ecological models of behaviour change are multifaceted and are concerned with environmental change, in addition to individual factors, as well as the interaction between the two. This multilevel theoretical approach seems likely to have utility in implementing home safety programmes, whereby initiatives to change individual behaviour may be combined and supported with policy and regulatory initiatives. In applying an ecological framework to the prevention of unintentional home injuries, the influence of the individual and the influence of the home environment in unsafe practices can be brought together. Human behaviour and dwelling design have been shown to be important contributory factors in home accidents; structural features can present physical dangers (steps, stairs and balconies) and occupiers themselves can create additional hazards through their behaviour in interacting with these features (Bonnefoy et al, 2004). An ecological framework would also take into consideration the fact that the direction of influence can be bi-directional; behaviour can be influenced by the environment and the environment can also be influenced by behaviour.

In order to apply an ecological approach to home accident reduction, a fuller understanding of the role of the varying influences of both behaviour and design on home safety is desirable. The aim of the present investigation was, therefore, to gain an improved understanding of the different ways in which people use (and misuse) features within their home and to identify the varying ways in which occupier behaviour can interact with dwelling design to lead to safe or unsafe practices. 


\section{$2.0 \quad$ Method}

This study utilised a qualitative approach involving householder interviews and a home inspection to elicit in-depth information from individuals inhabiting a new home.

\subsection{Sample}

Participants in this study were recruited to achieve a structured convenience sample.

Over a period of four months, letters inviting participation were delivered to all completed and occupied properties on new build developments in the area of Leicestershire/Nottinghamshire within the UK. All known residential developments within a 20 mile radius of Loughborough University were targeted. In total 774 unsolicited letters were delivered to properties resulting in 40 participants, a response rate of 5\%. Two news releases were used during the course of the research to raise awareness of the study and to encourage participants to respond to the mailing. These resulted in several articles in local newspapers.

The primary criterion for inclusion in this study was new build occupancy within the previous two years. The sample composition intentionally covered a broad range of property types (detached house, semi-detached house, terraced house, town house and apartment) and reflected different types of occupancy status (owner occupier, tenant and shared accommodation). The properties were constructed by both small private firms and large commercial builders. 


\section{$2.2 \quad$ Research Design}

An interview schedule was prepared at the beginning of the study (Table 1). This was piloted with two households before producing the final version. In total, 40 face-toface, semi-structured interviews were conducted within the participant's home to collect information on the personal experiences of individuals inhabiting a new-build dwelling. Due to the nature of semi-structured interviewing, some participants spontaneously introduced interesting themes that were not within the interview schedule. Where topics were raised that were pertinent to the study objectives, the data have been included in the results.

Of the 40 interviews, 27 were conducted with a single participant; 13 were conducted with partners present. Where a single individual was interviewed, these were either sole occupiers of the property or the resident that made contact with the researcher. In total, 26 males and 28 females participated. The interviews were recorded with the knowledge and consent of the interviewees. The same researcher, trained in interview techniques, conducted each interview. Each interview lasted approximately one and a half hours.

At the conclusion of the interviews the researcher accompanied occupiers around their properties to identify where problems arose with design features and where modifications had been made. Each room was visited and the participants were asked to describe whether they had made any changes within that room or if they had experienced any problems or concerns regarding any features. Each home inspection followed up on the details provided during interview and was undertaken as a memory aid to assist give the participants in recalling and describing changes and problems. The 
time taken for this varied from property to property and was dependent on the number of changes made or the nature of the problem experienced by the participants. The typical duration was 30 minutes.

[Table 1 here]

\subsection{Analysis}

The recorded interviews were fully transcribed and the transcriptions were imported into the qualitative software tool, Nvivo. The qualitative data analysis followed three steps: data reduction, data display, verification and conclusion drawing (Miles and Huberman, 1994). Data reduction was achieved by coding the interview data using the qualitative data analysis software NVivo and subsequent pattern coding of the initial codes (Miles and Huberman, 1994). Validation of the coding was achieved by independent review of a sample of the data and subsequent interpretation by another experienced researcher, independent of the study. The sample data were independently coded by the two researchers, with coding applied to the same chunks of data. During subsequent discussion there were no disagreements between the two researchers over codes, definitions or blocks of data. The pattern coding from the qualitative analysis provided the basis for the data summary tables (Tables 2 and 3) from which the conclusions within this study have been drawn.

\subsection{Ethics}

This research was subject to and in compliance with the requirements of the Loughborough University Ethical Advisory Committee in relation to research with human participants. Informed consent was obtained from all participants. They were 
made aware that all information provided during the interviews would remain confidential and only reported in anonymised form.

\section{0 Results}

The mean length of occupation of the properties in this study was 12.5 months (SD = 8.6). The age of all those participating ranged from 20 to 65 years, (mean $=37.5$ years, $\mathrm{SD}=12.9)$. All participants were recruited on the basis of being the first occupiers of the property. Within the sample, 35 of the properties were owned by the occupants, 3 were rented properties and 2 were multi-occupancy houses. No other occupancy status was reported. Of the forty properties visited, 4 were classed as detached (separate houses), 3 as semi-detached (adjoined by one wall), 5 as terraced (adjoined by two walls), 20 as ‘town houses’ (terraced, detached and semi detached with three storeys) and 8 were apartments/flats (one floor only). This range of property types together with the varying status of occupiers ensured that the study captured the experiences of both owners and tenants within a variety of dwelling types. The sample drew properties from 11 different house builders/developers and whilst not all UK developers were represented, the composition of house types studied reflects current trends in building styles within the UK (ODPM, 2004a).

The main findings from this study are displayed in the data summary tables (Tables 2 and 3). Table 2 illustrates the unsafe behaviours reported by participants as a result of their interaction with a building feature. Table 3 illustrates the building features, which were considered by participants as hazardous. Only those issues that were explicitly identified during the interviews are presented; these are unlikely to be exhaustive. 
[Table 2 here]

[Table 3 here]

\subsection{Unsafe Behaviour}

Among the 40 properties, 26 were fitted with internal self-closing fire doors in line with current UK Building Regulations. These regulations stipulate that within dwellings with a floor higher than $4.5 \mathrm{~m}$ above ground level, the upper storeys (those above ground level) should be served by a protected stairway leading to at least two escape routes at ground level, each delivering to final exits and separated from each other by fireresisting construction and self-closing fire doors (ODPM 2004b). In dwellings classed as flats, where all habitable rooms have direct access to an entrance hall, they should have a protected entrance hall (ODPM 2004b). All of the town houses $(n=20)$ and 6 of the flats fell under these requirements. The remaining 14 properties were exempt from the requirement for fire doors.

In the 26 properties with internal fire doors, the doors were located on habitable rooms in line with requirements, but in some, additional fire doors were found to be installed on bathrooms and also airing cupboards. The provision of these going beyond what is required by legislation. In all of the properties with fire doors, the owners/occupiers had interfered with the mechanism of the doors in some way. Participants reported interfering with the self-closing mechanism itself in 9 of the properties and in 25 of the properties, fire doors were wedged open in some way preventing them from closing (Table 2). Although these were not irreversible interferences, in that the wedges could have been removed and the self-closers replaced, and not illegal in any way, the act of 
disabling the doors resulted in reduced fire protection for all occupants within each dwelling. Of these 26 properties, 22 were occupied by the owners, 2 were rented flats and the remaining two properties, both town houses, were multi-occupancy dwellings (each bedroom being rented to separate individuals). Although participants had interfered with this safety feature, some reported that they felt they were a good idea and they did appreciate the safety reasons for the installation of the doors.

A 25-year-old male living in shared accommodation said:

'I think obviously they are a good idea..[but] I'm sure there's another way of doing it'

A 35-year-old married female commented:

'I understand the health and safety behind it but it drives me [mad], it worries me, they really go [close] with a bang'

A 51-year-old female homeowner said:

'I understand why they are there, they are there for safety but they are a bliming nuisance,

Some participants explained why they disabled their fire doors, these explanations included inadequate internal lighting when the doors are shut, noise due to the doors slamming and the prevention of finger-trapping injuries. A full breakdown of these reasons is given in Figure 1. Where the reason is unspecified, the participants did not provide an explanation for interfering with the fire doors.

[Figure 1 here] 
Unsafe behaviour was also reported in conjunction with the use of other design features and systems within the home. Of the 40 properties visited, 32 had been built with a loft (roof void accessible via a hatch), and a purpose built extending loft ladder had been fitted by the occupiers in only 5 of these properties. A loft-ladder had not been provided as standard by any of the house builders. In the remaining properties, access to the loft was achieved by various means including the use of general-purpose ladders, stools, chairs, furniture and fixtures. Of those that had accessed their loft $(n=24), 8$ reported no problems in using such items to gain access, but for some $(n=12)$ this was a cause for concern. Within the UK, the location of the loft hatch is typically positioned in the ceiling on the top landing of the property and whilst participants were not directly asked about the location of their loft access, some participants spontaneously commented on this.

A 33-year-old male described how he had fallen from the loft access hatch when the furniture he was standing on turned over:

'So I could have fallen down the stairs quite easily. It's right next to the stairs. It fell that way fortunately, if it hadn't, I would have gone over the stairs.'

A 34-year-old homeowner described the positioning of the loft access hatch and how he saw this as creating a hazard:

'If you look up there, you've got the loft hatch and if you've got a step ladder, you would have to step on the top rung and try and grab yourself into the loft, but it's a sheer drop right down the stairs, there's no room for error, you're not going to land on the landing, you are going to go straight over.' 
Unsafe behaviour was also reported in relation to DIY tasks undertaken within the home, specifically in relation to electrical safety and the water supply. In all the properties visited, the service cabling and piping were located behind plasterboard within the walls. Of those interviewed, $27 \%$ reported that they did not consider or seek to locate the routes of these services before drilling into the wall. Risks typically arose when hanging pictures, curtain rails or putting up shelving. A number of occupiers (40\%) stated that they were unaware of the location of these services but did consider where they might be when drilling. These households did not use a services detector tool but reported that they were careful not to drill into walls near electrical sockets or in the vicinity of radiators. Only $21 \%$ of the households had purchased a services detecting tool. Of these, 2 of the tools located electricity cables only and in one instance, because of this, a water pipe had been damaged as a result of drilling. Only 2 of the households recalled being given a services map by the house builder outlining the location of electricity cables. However, a corresponding map for the for the water pipes was not provided. In the remaining properties $(n=2)$, occupiers reported having knowledge of the location of these services because they had visited the property whilst it was being built and had taken photographs of the piping and cabling before the walls had been plastered.

All of the properties visited were fitted with a mains powered smoke alarm with a battery as a secondary power supply. They were located within the homes in accordance with UK Building Regulations (ODPM 2004b). No physical check was made of these smoke alarms by the researcher. In 13 of the properties, the occupant had experienced false activation of the smoke alarm during food preparation. In 15 of the properties, the occupants had not tested the battery within their smoke alarm since 
moving into the property, and in 8 properties where occupants stated they made regular checks of the smoke alarm, the frequency of these checks varied between 3 months and 12 months. Smoke alarm manufacturers typically indicate that weekly tests are required.

\subsection{Building Features and Systems}

Participants reported specific problems in relation to a number of design features and systems within their home. These are summarised in Table 3.

A water thermostat, allowing the occupiers to adjust the temperature of the hot water was fitted in 21 of the properties within this study. No adjustable hot water thermostat was fitted in 14 homes and participants from 5 properties reported that they were either unsure or did not know if a water thermostat was fitted. In 5 of the properties with an adjustable water thermostat, the temperature setting had been altered by the occupiers and in all these cases the temperature had been turned down. Excessive hot water temperatures, sufficiently hot to cause scalding, were reported by 6 participants. Of these, 4 had a water thermostat fitted, although only two had made adjustments to this. In the remaining 2 properties where excessive water temperatures had been reported, no thermostat was fitted. In both of these homes, scalds were reported due to the temperature of the hot water. No check was made of the actual water temperature within these homes during the course of the study.

Safe limits on the delivery of hot water within dwellings are not contained currently within Building Regulations. However, a recent move to bring thermostatically controlled mixing valves within the scope of building control has been announced 
(ODPM 2004c), in an attempt to address the number of accidental burn and scald cases. Mixer valves, whereby hot and cold water are mixed at the point of use, had been fitted into some bathrooms but the design of these mixer valves was not always such as to prevent the problem of scalding.

A 21 year old female described the problem with her mixer taps, whereby the water was not sufficiently mixed to prevent scalding:

'Even when you have hot and cold on at the same time it still comes out in columns, and if you put your hand under, ironic as it sounds you can still actually scald yourself, even though the cold water's there'

In 2 of the 40 properties, the occupiers identified stair newel posts as dangerous features within their homes (newel posts are located at the top and bottom of a stair case and positioned at stair turns for structural support). These presented a risk of head injury resulting from impact. Building Regulations state that a clearance of 2 meters is adequate on the access between two levels (ODPM 2003). The height of the newel posts identified in this study were not measured, but an example of one where the occupier reported concerns is shown in Figure 2.

Another feature that presented an increased risk of impact or head injury was sloped internal ceilings. These were located above the stairs in some properties and also within the bathrooms on the top floor of three story properties. No regulatory advice is provided within the UK regarding the minimum height of ceilings within domestic buildings, and whilst a number of occupiers reported no problems with sloped ceilings within their homes, in 3 properties visited, occupiers complained of having struck their head due to these low ceilings. 
Sloped or ramped external access to properties, were suggested by 2 participants as presenting an increased risk of slips and falls during bad weather. UK Building Regulations require the surface of such approaches to be smooth; suitable for use in a wheelchair (Powell-Smith \& Billington, Section 17.26). Participants from these two properties reported that the floor surface of the external access became slippery during adverse weather conditions.

Some participants mentioned during interview that the emergency egress window(s) within their properties were a concern, particularly for children in relation to falls. A window provided for emergency egress purposes should have an unobstructed openable area that is at least $0.33 \mathrm{~m}^{2}$ and at least $450 \mathrm{~mm}$ high and $450 \mathrm{~mm}$ wide, (ODPM 2004b). In 18 of the properties occupiers reported having an emergency egress window fitted to windows above the ground floor. In the remaining properties, the occupiers stated they were not aware of having a designated fire window. Of the 18 homes fitted with these windows, 13 of these were not fitted with a window lock. In 8 of the properties the opening of the window could be limited by a specific window restrictor bar, which could be over ridden in an emergency. In 6 properties the windows could not be locked or restricted in any way (Figure 3). In one property, the route to the egress window had been obstructed due to the occupiers using the room for storage. As stated by the 24 year old female occupier:

'You can't actually get to the windows, there is clutter in front of the windows.'

Six participants from different properties also reported a lack of lighting, both internal and external as being a cause for concern. A lack of internal lighting was reported on 
internal stairways leading to a concern over falling and a lack of external lighting led to concerns regarding both falls and also personal safety when outside the home.

\subsection{Discussion}

This study has provided further evidence for how architectural features and human behaviour have the potential to cause accidental injury within the home, in line with Bonnefoy et al, (2004). The investigation has shown how structural features may present physical dangers (e.g. fire egress windows, loft access hatches) and also how behaviour of occupiers whilst interacting with the feature can create additional hazards (e.g. interference with fire doors). Although there are prescribed requirements in relation to the design and construction of new homes within the United Kingdom in relation to safety, the findings of this research suggest that the interaction between specific features and occupier behaviour still leaves a continuing risk of injury with current house designs.

Previous injury prevention programmes have focussed on changing behaviour within the home or changing the home environment itself. These approaches often have not considered the complex interactions that arise between occupiers and building features. Neither has adequate recognition been given to the fact that for primary design interventions, a behavioural adaptation may also be required (Carlson Gielen \& Sleet, 2003). It is therefore important that prevention measures target both of these aspects. An ecological approach to the reduction of home injuries would address both behavioural influences and environmental influences. By considering behaviour in conjunction with the physical environment, potential hazards that may arise as a result of an interaction may be preventable. For example, primary interventions aimed at 
changing the environment itself may be supported by behavioural approaches aimed at both attitude and behaviour change.

This study has identified a number of unsafe behaviours practised by occupiers, arising as a direct result of the occupants' interaction with the building features and systems within the home. It is striking that in each of the homes fitted with self-closing fire doors, the occupiers had interfered with the fire-door mechanism in some way thereby reducing the level of protection afforded through their installation. If the results of this study are indicative of behaviours practised in other homes, as suggested by Pickett (2003), the provision of internal self-closing fire doors may be largely ineffective as a safety measure. Pickett suggested that occupiers were likely to interfere with the selfclosing mechanism due to the usability issues associated with the fire doors, and this suggestion accords with the findings of the present study. The fact that some participants recognised the benefits of having fire doors fitted and understood the health and safety reasons behind their inclusion, yet still interfered with their fire doors indicates the significant practical problems users found with this safety measure. This highlights why engineered fire protection in the home needs to consider human behaviour from the outset if it is going to afford protection to occupants (Meacham, 1999). In addition to this, improved design of the self-closing mechanism might be a means for eliminating the hazard of finger trapping injuries.

Notwithstanding the problems found with some existing safety measures in new homes, it is evident that there may be scope for other interventions to improve safety. The increased risk of falls, presented by occupier behaviour in accessing the loft for example, may be prevented by an ecological approach addressing both the behavioural 
component of this risk and a legislative requirement for the provision of loft access ladders in all new dwellings. In other words, a safety awareness campaign complemented with housing action (Ormandy, In Press). A typical cost of an individual loft access ladder, including installation is of the order of $£ 150$. The location of the loft access hatch itself also warrants consideration; through addressing the design specifications of this feature and positioning it away from the stairs, this would remove the potential risk for serious falls occurring. The cost implications associated with this type of approach may be minimal, particularly if it is addressed early on in the design phase. Whilst there are cost implications for both approaches, the contribution of improved design in reducing the number of accidental falls within the home may in the long term far outweigh the initial one-off cost (Pauls, 1991).

Safety in relation to electrical cables and water pipes within new homes could also be improved. If the layout of pipes and cables was standardised or details of their route were included within the homeowners information packs, (as suggested by a number of participant's within this study) this may go someway towards informing occupiers as to the location of such items and prevent risk-taking behaviour when drilling through walls. Some participants in this study used photographs taken prior to completion to inform them of the location of services within their home. This may be an idea that could be incorporated into the homeowners packs with minimum cost to the house builder.

A number of other problems reported by participants during this study may also be largely preventable though an ecological approach, supporting alternative design and behaviour modification. The re-design of stair newel posts and sloped internal ceilings 
would reduce the risk of unintentional head injury and the provision of storage might lessen the amount of clutter and reduce the potential for slips, trips and falls. Improved design of fire egress windows may reduce the risk of falls from a height; yet still allow safe egress in case of emergency. In all of these examples, behaviour-based strategies may complement any changes in design.

Although this study has identified shortcomings with some of the safety measures incorporated in the current generation of dwellings, it ought to be recognised that there are other safety measures installed that are effective. For example, residual current devices, (protective switches that interrupt the electrical current if the circuit develops a fault or problems with the equipment occur) are successful in providing protection against electric shock. Another commonplace example is the use of safety glass in glazed doors and partitions, reducing significantly the risk of laceration injury. It is interesting to observe that among the reasons these safety features is because they fulfil their function whilst being unobtrusive. A behavioural adaptation is not required for their operation to maintain efficiency and they do not interfere with user priorities and requirements.

Critiquing the study methodology, the retrospective nature of the study relied heavily on participants' recollections of their experiences at a busy and sometimes stressful period and it is possible that information may have been missed because of this. The sample of participants were self-selecting and those participating may have held particularly strong views or had particular experiences, motivating their participation. The study involved participants drawn from 40 properties, and whilst wide generalisation is not appropriate with this sample size, the results are illustrative and informative. 


\subsection{Conclusions}

This study has examined how people interact with the current generation of new dwellings in the UK from a safety perspective. The findings show that some installed safety features are a source of inconvenience for occupiers, sometimes introducing additional injury hazards. The findings have also highlighted the importance of the interaction between human behaviour and dwelling design, an aspect which may hitherto have been neglected. It should be evident that design features or systems within dwellings, aimed at improving health and safety, with which occupiers will actively engage, need to consider the user side of this interaction.

The findings of this investigation should be of interest to those responsible for the development of building standards, procedures and guidelines, providing further information regarding the influence of occupier behaviour. The findings should also be of benefit to agencies responsible for promoting home safety through illustrating the problems occupiers experience with features and how these problems might be avoided through alternative design. 


\section{References}

Bonnefoy, X.R. et al, 2004. Review of evidence on housing and health; Background Document. Fourth Ministerial Conference on Environment and Health, Budapest, Hungary, 23-25 June 2004.World Health Organisation.

Carlson Gielen, A \& Sleet, D., 2003 Application of Behavior Change Theories and Methods to Injury Prevention. Epidemiological Reviews. 2003; 25 : 65 - 76.

Dejoy, D.M., 1996 Theoretical Models of Health Behavior and Workplace SelfProtective Behavior. Journal of Safety Research Vol 27, No. 2.

Department of Trade and Industry, 1999. Research on the patterns and trends in home accidents, Department of Trade and Industry, London.

Department of Trade and Industry, 2003. $24^{\text {th }}$ (Final) Report of the Home and Leisure Accident Surveillance System - 2000, 2001 and 2002 data, Department of Trade and Industry, London.

Eime, R., Owen, N. \& Finch C., 2004 Protective Eyewear Promotion. Sports Med. 34 (10) $629-638$. 
Haslam, R., Hill, D., Sloane, J., Howarth, P. and Brooke-Wavell, K., 2006. Behaviour and the safety of older people on stairs. In: Understanding and Preventing Falls (edited by R Haslam and D Stubbs) (Taylor \& Francis, CRC Press: Boca Raton, Florida), pp 209-234.

Heimplaetzer, P.V., Goossens, L.H.J., 1991. Risks and accidents in the built environment. Safety Science, 14, 87 - 103.

McLeroy, K.R., Bibeau, D., Steckler, A. \& Glanz, K., 1988 An Ecological Perspective on Health Promotion Programs. Health Education Quarterly 1988, 15, 351 - 377.

Meacham, B.J., 1999 Integrating human behaviour and response issues into fire safety management of facilities. Facilities. Volume 17, (9/10) 303-312.

Miles, M.B., Huberman, A.M., 1994. Qualitative Data Analysis, An Expanded Sourcebook. Sage Publications.

Office of the Deputy Prime Minister, 2003. Approved Document K Protection from falling, Collision and Impact. HMSO

Office of the Deputy Prime Minister, 2004a Live tables on stock, Table 117 : Dwelling stock - type of accommodation, by region, Taken from http://www.odpm.gov.uk/index.asp?id=1156006 , accessed $4^{\text {th }}$ May 2006. 
Office of the Deputy Prime Minister, 2004b The Building Regulations 2000, Approved Document B, Fire Safety (2000 Edition with 2002 amendments) HMSO

Office of the Deputy Prime Minister, 2004c News Release 2004/0002. Government moves to stop bath-time scalding injuries.

http://www.communities.gov.uk/index.asp?id=1002882\&PressNoticeID=1438 Accessed 30 ${ }^{\text {th }}$ May 2006.

Ormandy, D. (In press). Home - Haven or Accident Black Spot? A Review of the Causes of Home Accidents. Int. J. Environment and Pollution.

Pauls, J., 1991. Safety standards, requirements, and litigation in relation to building use and safety, especially safety from falls involving stairs. Safety Science, 14, 125 - 154.

Pickett, J.W., 2003. Report on the finger-trapping hazard created by fire doors installed in two types of three story houses. Report prepared on behalf of The Royal Society for the Prevention of Accidents. ROSPA, Birmingham.

Powell-Smith, V. \& Billington, M.J., 1999. The Building Regulations Explained and Illustrated. Blackwell Science, Oxford.

Rennie, D.M. \& Ford, N.J., 1995. Design of dwellings and accidents involving children. The Royal Institution of Chartered Surveyors: London. ISBN 0-85406-739-6. 
RoSPA, 2005. Modernisation fund. Interventions to prevent accidental injury in the home. Rospa.

Roys, M., 2001. Serious stair injuries can be prevented by improved stair design, Applied Ergonomics 32, 135 - 139.

Secretary of State for Health, 1999. Saving Lives: Our Healthier Nation. The Stationary Office, London.

Shults, R.A., Sacks, J.J., Briske, L.A., Dickey, P.H., Kinde, M.R., Mallonee, S. \& Douglas, M.R., 1998. Evaluation of Three Smoke Detector Promotion Programs. Am J Prev Med 1998, 15 (3)

Whysall, Z.J., Haslam, C.O. and Haslam, R.A., A staged approach to reducing musculoskeletal disorders (MSDs) in the workplace, 2005, pp 1-77, Health \& Safety Executive, RR379 HSE Books, Sudbury . 
Table 1 Interview schedule.

\begin{tabular}{|c|c|}
\hline Topic & Content \\
\hline Personal details & $\begin{array}{l}\text { Gender. Age. Occupier status. Length of occupation. } \\
\text { Household composition. }\end{array}$ \\
\hline $\begin{array}{l}\text { Facts about the } \\
\text { property }\end{array}$ & $\begin{array}{l}\text { Type of property. Number of bedrooms. Purchase price. } \\
\text { Name of builder. Stage of construction at purchase. } \\
\text { What changes did you ask the builder to make prior to completion.? } \\
\text { Did you compile a snagging list? } \\
\text { What information was provided about the property? } \\
\text { How much of this information has been read? } \\
\text { How were you introduced to the features within your home? } \\
\text { Were you told about any safety features within your home? } \\
\text { How were you introduced to the safety features within your home? }\end{array}$ \\
\hline $\begin{array}{l}\text { Changes made to } \\
\text { property }\end{array}$ & $\begin{array}{l}\text { What changes have you made to the property? } \\
\text { Why did you make these changes? } \\
\text { What changes are planned for the future? } \\
\text { Would you undertake these changes yourself or employ a } \\
\text { professional? What would influence this decision? } \\
\text { Do you engage in DIY activities? } \\
\text { Restrictions to making changes to property? } \\
\text { Have you made any of the following changes: } \\
\text { - Erected any additional walls. } \\
\text { - Replaced any glass. } \\
\text { - } \quad \text { Drilled through any floors. } \\
\text { - Removed members in roof construction for loft access. } \\
\text { - Removed any fire doors due to inconvenience. } \\
\text { - Removed the door closers on fire doors. } \\
\text { - Removed gravity-driven rising butt hinges. } \\
\text { - } \quad \text { Blocked any air vents. } \\
\text { - Installed additional electrical sockets. } \\
\text { - Changes stepped approaches to sloped approaches. } \\
\text { - } \quad \text { Removed hand rail from stairs. } \\
\text { - Installed recessed down lighters in ceiling. } \\
\text { - Removed smoke alarm battery due to false alarms. } \\
\text { - Fitted security locks on windows. }\end{array}$ \\
\hline
\end{tabular}

Use of Property

Are there any rooms that you do not use for their intended purpose? Do you use the loft for storage?

How do you gain access to the loft?

Do you have a garage?

What do you use the garage for? 


\begin{tabular}{ll}
\hline Topic & Content \\
\hline Safety features & Do you have: \\
& - Restrictor catches on upstairs windows? \\
& - Hater thermostat? Do you know what the temperature is? \\
Home safety & How do you have/not have these items? \\
& Have you or any member of the household has a home accident? \\
& Are you concerned about any features within your home? \\
Have you experienced any problems with the features within your \\
home? \\
About the Garden \\
What sort of garden do you have? \\
Have you undertaken any heavy garden work? \\
Do you feel your garden presents any risks to your health and \\
safety?
\end{tabular}


Table 2. Unsafe behaviour identified as arising through interaction with building feature.

\begin{tabular}{|c|c|c|c|}
\hline $\begin{array}{l}\text { Building } \\
\text { Feature/System }\end{array}$ & Reported Behaviour & Causal Factor/s & $\begin{array}{l}\text { Health and Safety } \\
\text { Risk/s }\end{array}$ \\
\hline Fire Doors & $\begin{array}{l}\text { Removal of self-closers. Wedging of } \\
\text { fire doors } \\
\text { 'We picked up on why there were } \\
\text { chains on all the doors } \\
\text {...so we moved in and took them all } \\
\text { off [closers]' } \\
\text { 'We've taken three closers off and } \\
\text { we've got two wedges, so we wedge } \\
\text { open the other two' }\end{array}$ & $\begin{array}{l}\text { Inconvenience. Noise. } \\
\text { Lack of light. Trapping } \\
\text { hazard } \\
\text { 'Otherwise they would } \\
\text { slam shut all the time, } \\
\text { also it's irritating when } \\
\text { you are moving through } \\
\text { the house carrying things } \\
\text { etc' }\end{array}$ & $\begin{array}{l}\text { Reduced fire protection. } \\
\text { Laceration risk from } \\
\text { tampering with spring } \\
\text { loaded closure } \\
\text { mechanism. }\end{array}$ \\
\hline $\begin{array}{l}\text { Loft Access (roof } \\
\text { void) }\end{array}$ & $\begin{array}{l}\text { Use of inadequate ladders and step } \\
\text { ladders to access the loft. Using } \\
\text { various items of furniture to stand } \\
\text { on to gain entry. Use of banisters } \\
\text { as a step up. Relying on a family } \\
\text { member for assistance } \\
\text { 'I've clambered up there using stools } \\
\text { and using B [wife] to stand on, it's } \\
\text { quite bad' } \\
\text { 'dangerously, there's a railing, the } \\
\text { top of the railings of the stairs and I } \\
\text { get a chair and put one foot onto the } \\
\text { railing and use brute strength to pull } \\
\text { myself up' }\end{array}$ & $\begin{array}{l}\text { 'we had just moved in } \\
\text { and wanted to get things } \\
\text { up there' }\end{array}$ & Falls \\
\hline $\begin{array}{l}\text { Electricity cables } \\
\text { and water pipes }\end{array}$ & $\begin{array}{l}\text { Drilling through walls without } \\
\text { considering the location of pipes or } \\
\text { cables } \\
\text { 'I've knocked a nail into the wall and } \\
\text { crossed fingers nothing's happened' } \\
\text { 'I'd just take a guess and hope for the } \\
\text { best' }\end{array}$ & $\begin{array}{l}\text { Insufficient knowledge } \\
\text { of location of services } \\
\text { 'No idea,..so no, no idea } \\
\text { where they were. It's } \\
\text { just straight in' }\end{array}$ & $\begin{array}{l}\text { Electrical shock. } \\
\text { Inadequate occupier } \\
\text { repair }\end{array}$ \\
\hline Smoke Detectors & $\begin{array}{l}\text { Not checking battery within smoke } \\
\text { alarm } \\
\text { 'Battery backup and no we haven't } \\
\text { tested it yet' } \\
\text { 'Supposed to check them every year } \\
\text { aren't you?' }\end{array}$ & $\begin{array}{l}\text { Insufficient knowledge } \\
\text { of item } \\
\text { 'I think it might be purely } \\
\text { battery operated, I can't } \\
\text { remember' }\end{array}$ & Reduced fire protection \\
\hline
\end{tabular}


Table 3 Building and design features and health and safety concerns expressed by occupier's.

\begin{tabular}{|c|c|c|}
\hline $\begin{array}{l}\text { Building } \\
\text { Feature/System }\end{array}$ & Reported Concerns & Health and Safety Risk/s \\
\hline Hot water system & $\begin{array}{l}\text { Excessive water temperatures } \\
\text { 'We have tried to tell them [house builder] } \\
\text { that the water is too hot, even I can burn } \\
\text { myself, what about the little one?' }\end{array}$ & Burns and scalds \\
\hline $\begin{array}{l}\text { Descending newel } \\
\text { posts }\end{array}$ & $\begin{array}{l}\text { Insufficient head clearance } \\
\text { 'I whack my head on there [descending } \\
\text { newel post]. } \\
\text { I think that's bad design, because it's } \\
\text { quite sharp.' }\end{array}$ & Impact injuries \\
\hline Sloped ceilings & $\begin{array}{l}\text { Insufficient head clearance } \\
\text { 'the roof above the stairs...but I've } \\
\text { banged my head on it twice' }\end{array}$ & Impact injuries \\
\hline $\begin{array}{l}\text { Sloped external } \\
\text { access }\end{array}$ & $\begin{array}{l}\text { Slippery in cold and icy conditions } \\
\text { 'it makes a ski ramp when there is frosty } \\
\text { conditions' } \\
\text { 'Sloped yeah, very dangerous with the ice } \\
\text { last week.' }\end{array}$ & Slips and falls \\
\hline Storage & $\begin{array}{l}\text { Insufficient storage within property } \\
\text { 'there's very little storage, therefore you } \\
\text { are leaving things lying around' }\end{array}$ & $\begin{array}{l}\text { Occupier modification, clutter leading } \\
\text { to slips, trip and falls }\end{array}$ \\
\hline $\begin{array}{l}\text { Fire Egress } \\
\text { Windows }\end{array}$ & $\begin{array}{l}\text { Child safety } \\
\text { 'There's fire escape windows, basically } \\
\text { the whole of the window opens, it's a } \\
\text { massive window which is safe for us, but if } \\
\text { you've got children, I suppose it would be } \\
\text { quite...[dangerous]' } \\
\text { 'Yeah, those windows are a huge risk } \\
\text { actually, a really big risk.' }\end{array}$ & Falls from height \\
\hline $\begin{array}{l}\text { Inadequate internal } \\
\text { lighting }\end{array}$ & $\begin{array}{l}\text { Darkness } \\
\text { 'once you get to the top of the stairs it's } \\
\text { dark, it's dingy' }\end{array}$ & $\begin{array}{l}\text { Occupier modification, slips, trips and } \\
\text { falls }\end{array}$ \\
\hline $\begin{array}{l}\text { Inadequate external } \\
\text { lighting }\end{array}$ & $\begin{array}{l}\text { Darkness } \\
\text { 'It makes me worry that I can't see where } \\
\text { I am stepping and I am going to fall' } \\
\text { 'It makes me worry about anybody who is } \\
\text { lurking about that I might be attacked' }\end{array}$ & Falls. Concern for personal safety \\
\hline
\end{tabular}


Figure 1.

Primary reason for fire door interference $(n=26)$

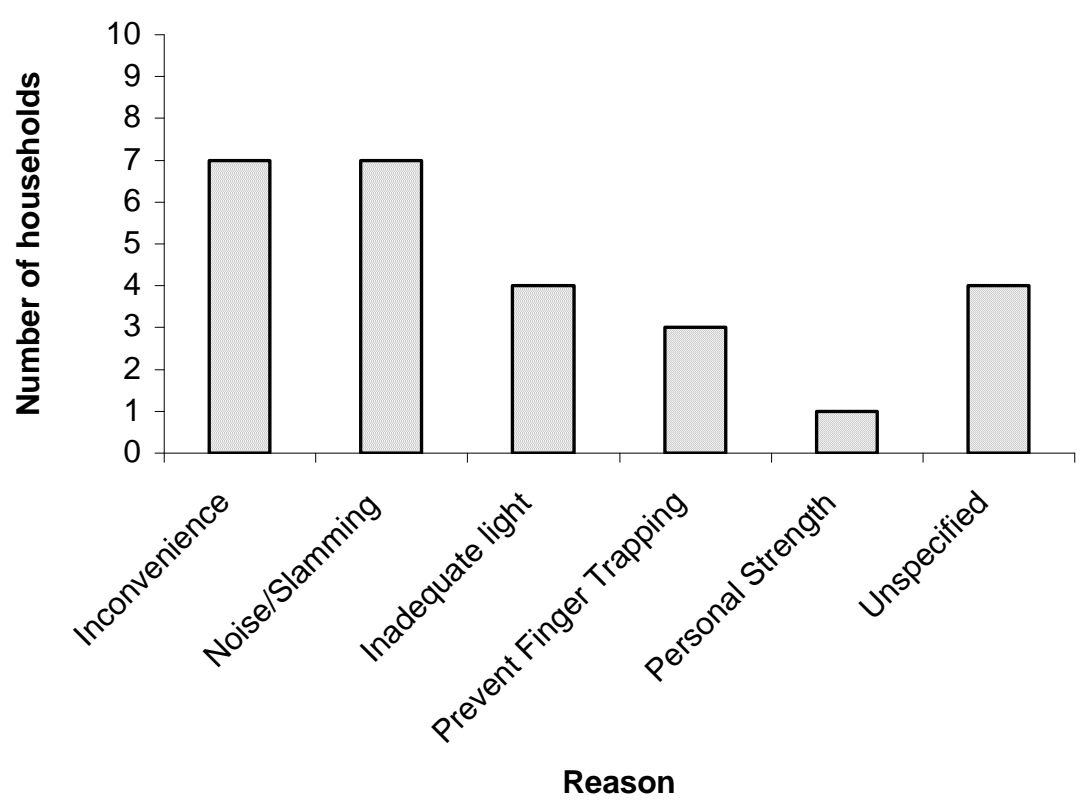


Figure 2. Photograph showing height of descending newel post (Household 21)

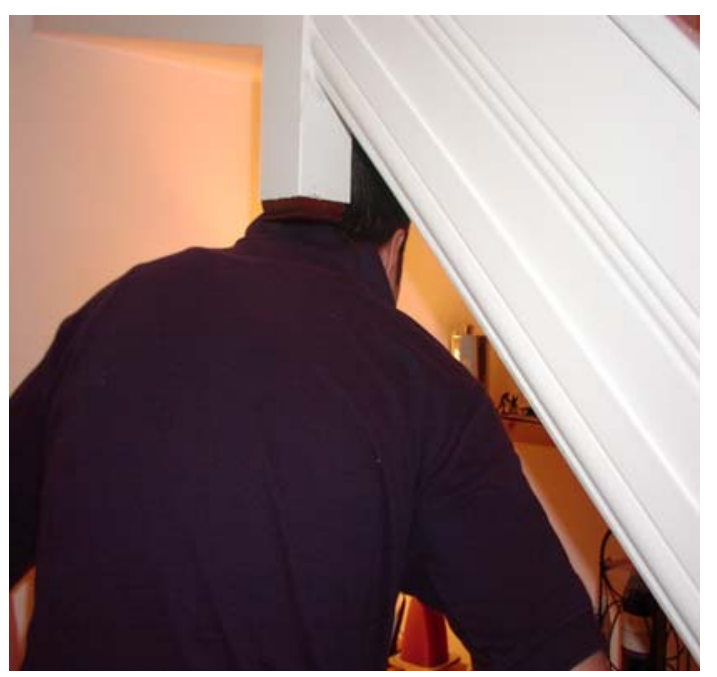


Figure 3. Photograph of emergency egress window located on $2^{\text {nd }}$ floor of building (Household 2)

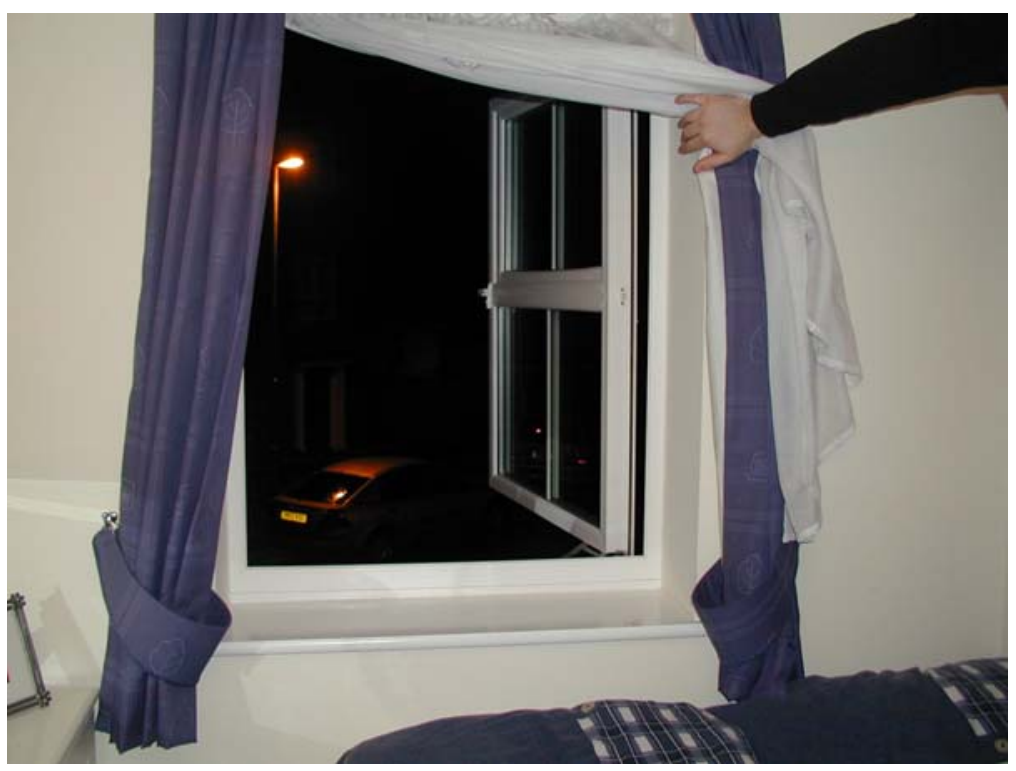

